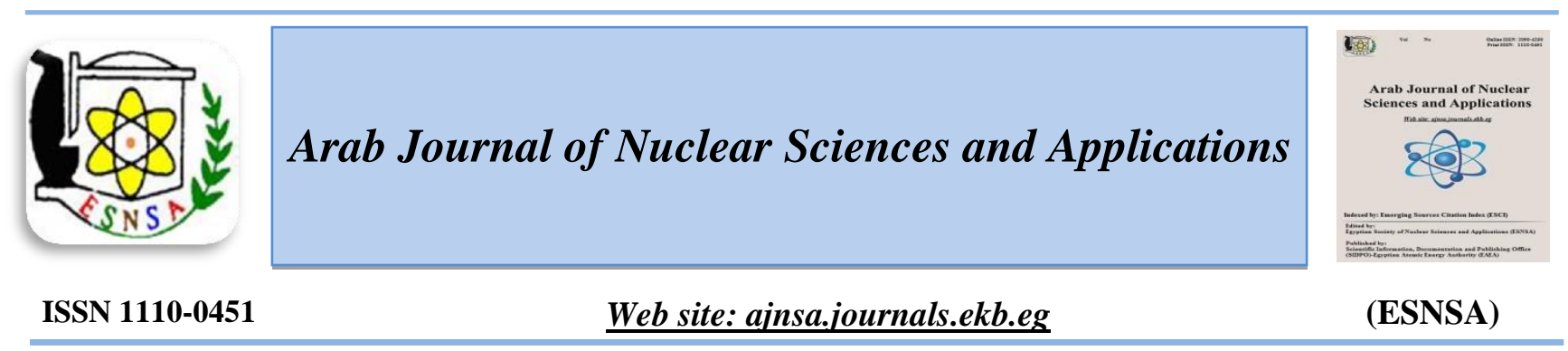

\title{
Characteristics of Biological and non-biological Aerosol Particles in Indoor Environment and their Inhalable Fractions in the Human Lung
}

\author{
Mona Moustafa \\ Physics department, Faculty of Science, Minia University, El-Minia, Egypt
}

Received $11^{\text {th }}$ Jul. 2019 Accepted 22 ${ }^{\text {nd }}$ Dec. 2019

\begin{abstract}
Air quality of public buildings is an important issue to assess human health. School and university buildings represent an important category of indoor environments. This study aims at evaluating the concentration and size distribution of fungal and non-biological aerosol particles in classrooms of Minia University, Egypt. In addition, the inhalable fractions were determined and indoor exposure dose (IED) of fungi and aerosols were estimated for the students. A six-stage Andersen impactor was used for collecting the fungal particles and Berner cascade impactor was used for sampling the non-biological aerosol particles. Indoor average concentration of fungi was $307 \pm 102 \mathrm{CFU} / \mathrm{m}^{3}$. The most frequently isolated genera were Aspergillus niger with concentration $175 \pm 85 \mathrm{CFU} / \mathrm{m}^{3}$ representing about $57 \%$ of the of the total collected fungi. Aspergillus flavus represents about $31 \%$ of the total fungi with concentration $96 \pm 32 \mathrm{CFU} / \mathrm{m}^{3}$. A low concentration $36 \pm 12 \mathrm{CFU} / \mathrm{m}^{3}$ of Penecillium was investigated representing only $12 \%$ of the total collected fungi. The mean concentration of non-biological aerosols was $442 \pm 99 \mu \mathrm{g} / \mathrm{m}^{3}$. The concentration of airborne fungal aerosol particles were lower than the World Health Organization guideline while the corresponding concentration of non-biological aerosols exceeded WHO limit. Most of the collected fungal particles were found in the inhalable size range $(<5 \mu \mathrm{m})$ where inhalable fraction of fungi represents $84 \%$ of the total collected particles while inhalable fraction of non- biological aerosols represents $92 \%$ of the total collected particles. Size distributions of biological and non-biological aerosols were bimodal in nature. IED of fungi was $25.6 \mathrm{CFU} / \mathrm{kg}$ while the IED of non-biological aerosols was 37 CFU/kg.
\end{abstract}

Keywords: Lead-free solders, $\mathrm{TiO}_{2}$ and $\mathrm{CuO}$ nano-particles, $\mathrm{Sn}$-Zn based alloy, microstructure, tensile creep properties

\section{Introduction}

Indoor air is a very dynamic system that contains a mixture of biological and non-biological aerosol particles $[1,2]$. Biological aerosols or microorganisms contain bacteria, fungi and viruses, attached to aerosol particles forming bioaerosols [3, 4] or organic compounds derived from these microorganisms such as endotoxins, toxins, metabolites and other microbial fragments in indoor environment $[5,6]$. Bioaerosols vary in size (from $20 \mathrm{~nm}$ up to $100 \mu \mathrm{m}$ ) and composition depending on the source, mechanisms of formation and the conditions of environment [7]. Bioaerosols are released from indoor and outdoor air including natural and artificial sources $[8,9]$. Indoor air is a predominant source of different bioaerosols [10].

Non-biological particles or aerosols are liquid or solid particles suspended in gaseous medium with a size ranging from $1 \mathrm{~nm}$ up to 100 $\mu \mathrm{m}$ [11]. Aerosols are generated by multiplicity of sources [12]. In indoor air, non-biological aerosol particles include tobacco smoke, motor vehicle emission particles, cooking-generated particles and organic and inorganic gases [13].

Biological particles contribute about $5-34 \%$ of the indoor air pollution [14-16]. Indoor air has more pollution than the outdoor air [17, 18]. Most people spend about $90 \%$ of their time in indoor

Corresponding author: mona_moustafa9@yahoo.com

DOI: 10.21608/ajnsa.2019.14716.1233

(C) Scientific Information, Documentation and Publishing Office (SIDPO)-EAEA 
environments, therefore the indoor air quality could significantly affect general health of human beings [19]. In many indoor environments, bacterial, fungal microbes and their fragments fall in the inhalable size range $(<5 \mu \mathrm{m})$ which can enter the lower parts of the respiratory system [9] and can cause different infectious diseases, allergic reactions, asthma and sick building syndrome (SBS) [20-24].

Fungal particles are one of the most important components of biological aerosol particles where fungi can cause a public health hazard [25]. The majority of indoor fungi is released from outdoor sources [26]. The deposition of fungal spores in the lung and their health effects depend on their composition, concentration and size [27].

High levels of particle pollutants are associated with decreased lung function, increased respiratory symptoms such as cough, shortness of breath, wheezing and asthma, as well as chronic obstructive pulmonary disease, cardiovascular diseases and lung cancer [28]. In recent years, indoor air quality has attracted public attention [29, 30]. The adverse health effects depend on the absorbed dose of air pollutants [31].

Therefore, the objectives of the present study are to: i) investigate the concentration and the size distribution of indoor fungi and aerosol particles ii) investigate the composition of the collected fungi; iii) estimate the inhalable fractions of fungi and aerosol particles; iv) estimate the indoor exposure dose (IED) of fungi and aerosol particles.

\section{Materials and methods \\ Sampling strategy}

Samples were collected from indoor air of lecturing rooms at Minia University (El-Minia/ Egypt) during a summer season (low occupancy period). The rooms have an area of about $50 \mathrm{~m}^{2}$. Minia University is located in the middle of ElMinia city, upper Egypt (Coordinates: $28^{\circ} 07^{\prime} 10^{\prime \prime} \mathrm{N} 30^{\circ} 44^{\prime} 40^{\prime \prime} \mathrm{E}$ ) located about $300 \mathrm{Km}$ south to Cairo. El-Minia map is shown in Figure (1). The university lies on a vegetation area from the west and on the highway of Cairo-Aswan from the east. While it is near to a residential area of North and South. Sampling was conducted during normal ventilation where windows and door were kept open. At least one run was taken a week for both biological and non-biological aerosols during the working days. The samplers were located about $1.3 \mathrm{~m}$ above the floor to simulate the breathing zone of the sitting students. Temperature and relative humidity were recorded during the sampling.

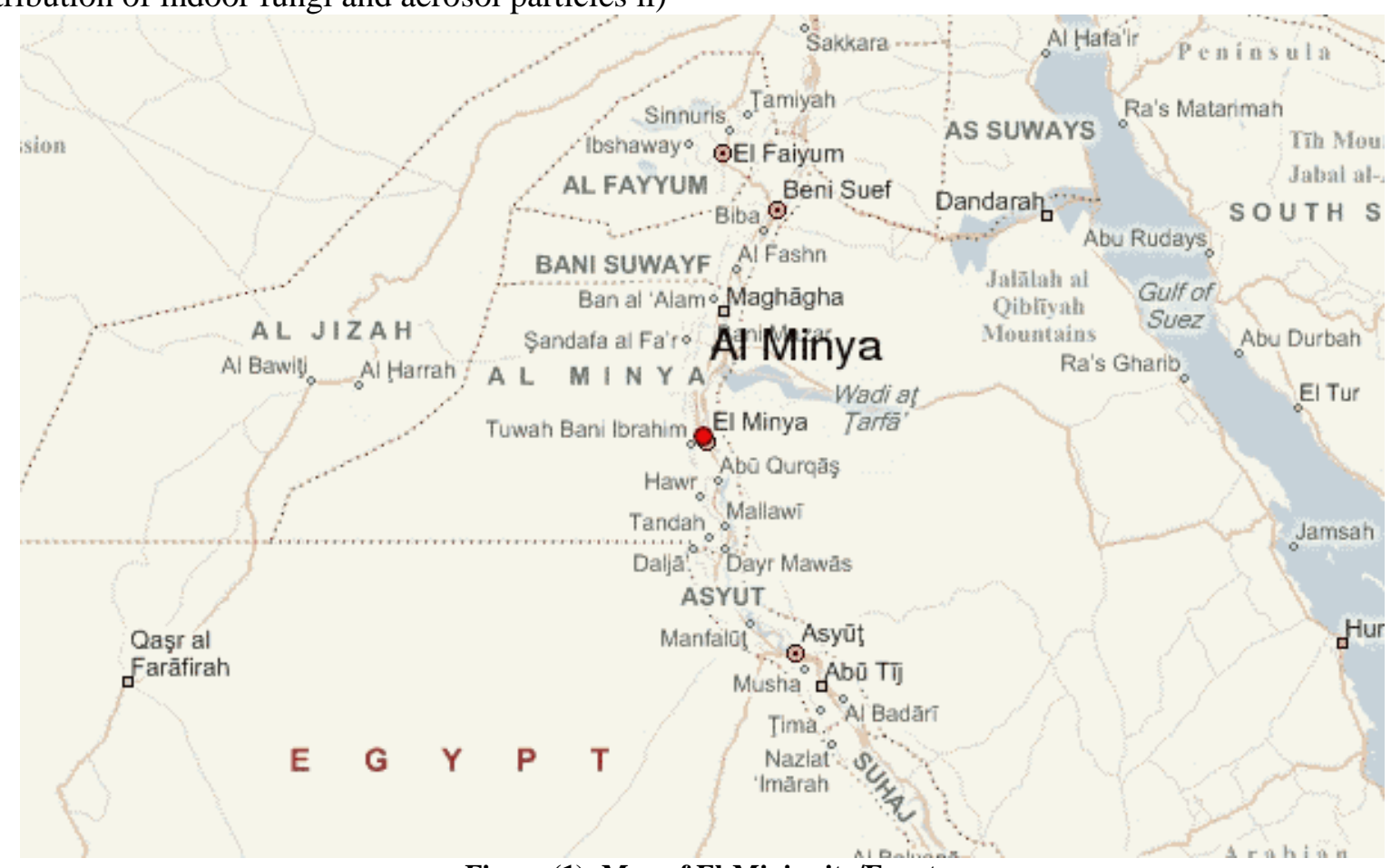

Figure (1): Map of El-Minia city/Egypt 
Biological aerosols sampling

Airborne fungi were collected using Six-stage Andersen impactor (ACI). The impactor is connected to a vacuum pump and a flow meter for operating at a constant flow rate of $28.3 \mathrm{~L} / \mathrm{min}$. Andersen impactor fractionates the collected microorganisms according to their aerodynamic diameters. The impactor sorts the viable particles into six fractions: $>7.0 \mu \mathrm{m}, 7.0-4.7 \mu \mathrm{m}, 4.7-3.3$ $\mu \mathrm{m}, 3.3-2.1 \mu \mathrm{m}, 2.1-1.1 \mu \mathrm{m}, 1.1-0.65 \mu \mathrm{m}$. The size of the impactor stages simulates the human respiratory tract regions. The collection efficiency of Andersen impactor was previously validated $[32,33]$. The impactor is calibrated so that all particles collected (regardless their physical size, shape or density) are sized aerodynamically and can be directly related to human lung deposition.

Sabouraud dextrose agar (SDA) supplemented with chloramphenicol was used as a culture media for collecting fungi. A volume of not less than 27 $\mathrm{ml}$ of culture medium was placed in each plate then they were inserted into each impactor stages. The sampling time of each run ranged from 10-15 min. This small time is chosen to avoid overestimated number of colonies. After microorganism sampling, the plates were incubated at $28{ }^{\circ} \mathrm{C}$ for 3-5 days and the total number of fungal colonies were counted. Based on the micro and macro morphological features, fungal isolates were identified by direct observation. The airborne bio burden was calculated in terms of colony-forming units per cubic meter air by Equation (1):

$$
C=\frac{n}{V . t} \ldots \ldots . . . c f u / m^{3}
$$

Where $\mathrm{n}$ is number of collected colonies on each stage of the impactor

$\mathrm{V}$ is the impactor flow rate in $\mathrm{m}^{3} / \mathrm{h}$.

$t$ is the sampling time in $h$.

\section{Non-biological aerosol sampling}

Aerosol particles were collected using low pressure Berner cascade impactor (BCI). The impactor is connected to vacuum pump operating at a flow rate of $1.7 \mathrm{~m}^{3} / \mathrm{h}$. Berner impactor has eight stages with cut-off diameters: $0.082,0.157$, $0.270,0.650,1.100,2.350,4.250$ and $5.960 \mu \mathrm{m}$. The impactor was calibrated in the isotope laboratory of Gottingen university, Germany [34].
Aluminum foils were used as a substrate for collecting the aerosols and a glass fiber filter as a backup filter. The sampling time of each run was 6 h. Filters and foils were weighted before and after sampling using a sensitive balance model Mettler analytical AE240 Dual Range Balance. Mass concentration (C) was calculated using Equation (2):

$$
C=\frac{m}{V . t} \ldots \ldots \ldots . \mu{ }^{3} / m^{3}
$$

Where $m$ is the particle mass collected on each stage in $\mu \mathrm{g}$,

\section{Results and discussion}

Concentration of fungal and non-biological particles

the mean concentration of airborne fungi and the most frequently isolated genera measured in indoor are summarized in Table (1). The mean concentration of airborne fungi was $307 \pm 102$ $\mathrm{CFU} / \mathrm{m}^{3}$. On one hand, the airborne fungal aerosol particles were lower than the World Health Organization guideline value of $500 \mathrm{CFU} / \mathrm{m}^{3}$ [35] and on the other hand, the present fungal concentration lie in a high level (301-1000 $\mathrm{CFU} / \mathrm{m}^{3}$ ) according to the categorization of [36].

Table (1) Concentration and inhalable fraction \% of fungi and non-biological aerosols

\begin{tabular}{|l|c|c|}
\hline \multicolumn{1}{|c|}{ Particles } & $\begin{array}{c}\text { Concentration } \pm \\
\mathrm{SD}\end{array}$ & $\begin{array}{c}\text { Inhalable } \\
\text { fraction\% }\end{array}$ \\
\hline Total fungi & $307 \pm 102 \mathrm{CFU} / \mathrm{m}^{3}$ & 84 \\
Aspergillus niger & $175 \pm 85 \mathrm{CFU} / \mathrm{m}^{3}$ & 91 \\
Aspergillus flavus & $96 \pm 32 \mathrm{CFU} / \mathrm{m}^{3}$ & 74 \\
Penicillium & $36 \pm 12 \mathrm{CFU} / \mathrm{m}^{3}$ & 93 \\
$\begin{array}{l}\text { Total aerosols } \\
\text { (nonviable) }\end{array}$ & $442 \pm 99 \mu \mathrm{g} / \mathrm{m}^{3}$ & 92 \\
\hline
\end{tabular}

The most frequently isolated genera were Aspergillus niger with concentration of $175 \pm 85$ $\mathrm{CFU} / \mathrm{m}^{3}$ representing about $57 \%$ of the of the total collected fungi. Aspergillus flavus represents about $31 \%$ of the total fungi with concentration of $96 \pm 32$ $\mathrm{CFU} / \mathrm{m}^{3}$. A low concentration of $36 \pm 12 \mathrm{CFU} / \mathrm{m}^{3}$ of Penecillium was investigated representing only 
$12 \%$ of the total collected fungi. The dominance of Aspergillus and Penecillium in the atmosphere may be attributed to their ability to grow in various substrata and meteorological conditions [37, 38]. Outdoor sources are considered the main source of indoor fungi [26].

Air quality standards for particulate matters are expressed in terms of mass concentration. The mean concentration of non-biological aerosols was $442 \pm 99 \mu \mathrm{g} / \mathrm{m}^{3}$. The present value exceeds the limit recommended $\left(120 \mu \mathrm{g} / \mathrm{m}^{3}\right)$ by World Health Organization, [39] and the limit value of 230 $\mu \mathrm{g} / \mathrm{m}^{3}$ suggested by the Egyptian law of Environment [40].

It was confirmed that human activity is an important factor for the emission of coarse particles while ambient aerosol concentration, which originates in traffic-related combustion process, affects the emission of fine particles [41].

Non-biological particles may serve as a carrier and source of nutrients for biological particles (bioaerosols) and at the same time affect their behavior and viability depending on particle composition and microorganism type and its tenacity to aerosol particles [42].

\section{Inhalable fraction of fungal and non-biological particles}

Transport and deposition of aerosols in the atmosphere and human lung depend mainly on the particle size [43]. Fine particles can penetrate deep in the respiratory tract [44]. Inhalable fraction $(<5$ $\mu \mathrm{m})$ of fungi is defined as the sum of the concentrations collected on the stage $3(3.3-4.7$ $\mu \mathrm{m})$, stage $4(2.1-3.3 \mu \mathrm{m})$, stage $5(1.1-2.1 \mu \mathrm{m})$ and stage $6(0.65-1.1 \mu \mathrm{m})$ of viable Andersen impactor with respect to the total concentration of fungi on all the six-stages of the impactor [45].

Concentration fractions $\%$ of fungi are summarized in Table (1) and are illustrated in Figure (2) from (a to d). Inhalable fraction of fungi represents $84 \%$ of the total collected particles; Aspergillus niger represents 91\%, Aspergillus flavus represents $74 \%$ and Penecillium represents $93 \%$. It is clear that most of the collected fungal particles were found in the inhalable size range. The present results are in agreement with those obtained in other studies $[41,46,47]$.
Inhalable fraction of non-biological aerosols is defined as the sum of the concentrations collected on the stage $3(2.35-4.25 \mu \mathrm{m})$, stage 4 (1.1-2.35 $\mu \mathrm{m})$, stage $5(0.65-1.1 \mu \mathrm{m})$ and stage $6(0.27-0.65$ $\mu \mathrm{m})$, stage $7(0.157-0.27 \mu \mathrm{m})$ and stage $8(0.082-$ $0.157 \mu \mathrm{m}$ ) of Berner impactor with respect to the total concentration of aerosols collected on all the eight stages of the impactor.

Concentration fractions $\%$ of aerosols is summarized in Table 1 and is illustrated in Figure (3). Inhalable fraction of aerosols represents $92 \%$ of the total collected particles. The presence of aerosol particles suspended in the air depends on their size that determines the mechanisms of the deposition and their residence time. This may explain the high percentage of fine particles in the collected sampled.

\section{Size distribution of fungal and non- biological particles}

Size distributions of indoor total fungi and isolated genera; Aspergillus niger, Aspirgillus flavus and penicillium are presented in Figure (4) from (a to d). The distributions are bimodal in nature according to the accumulation and the coarse modes. The highest concentrations were investigated at the size range $2.1-3.3 \mu \mathrm{m}$ for total fungi Aspergillus niger and Aspirgillus flavus with concentrations percentage $51 \%, 74 \%$ and $39 \%$, respectively. However, the highest concentration of penicillium was investigated at the size range $1.1-2.1 \mu \mathrm{m}$ with concentration $\%$ of 29 .

Aspirgillus flavus has the highest Median Aerodynamic Diameter (MAD) of $2.9 \mu \mathrm{m}$ while penicillium has the lowest MAD of $2 \mu \mathrm{m}$ and it was the more dispersed genus where the geometric standard deviation (GSD) was 2.2. Aspergillus niger has the lowest GSD of 1.6. Similar size distributions of bacteria and fungi were reported by other studies [31, 48-50]. 

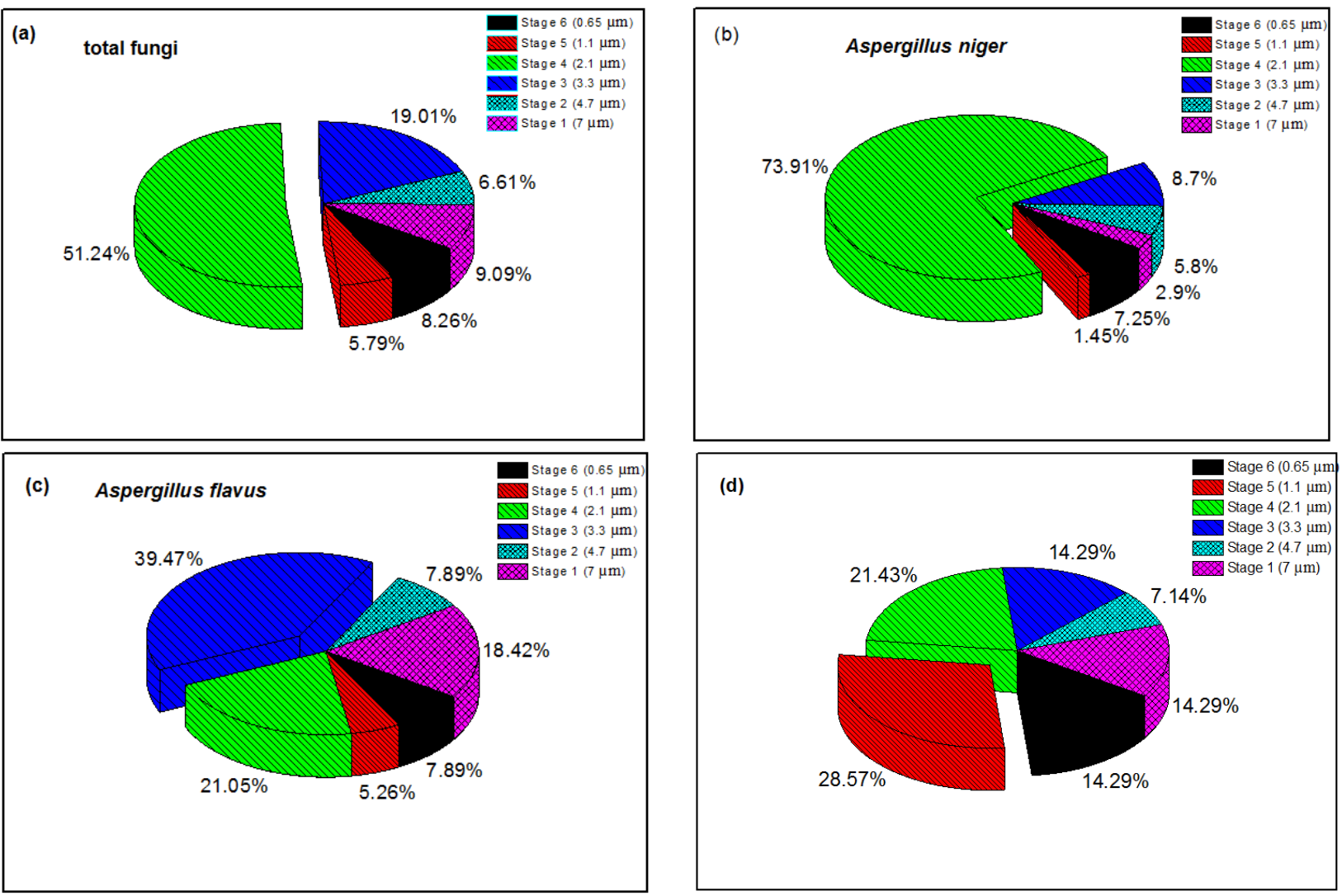

Figure (2): Concentration fraction $\%$ of isolated and total fungi

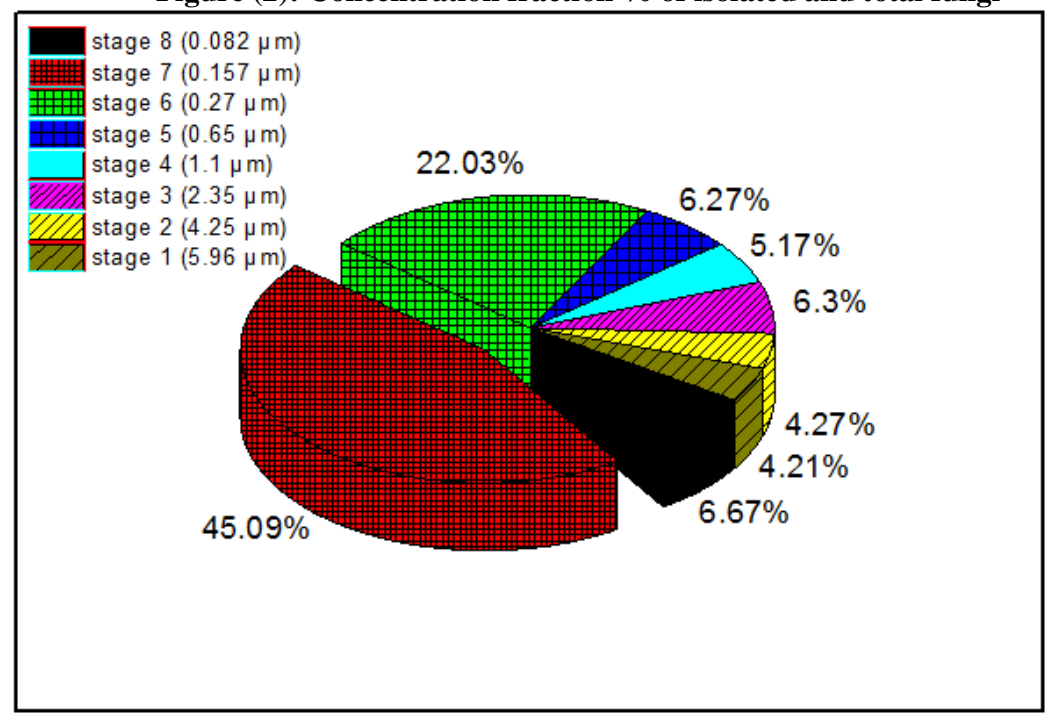

Figure (3): Concentration fraction \% of non-biological aerosols

Corresponding author: mona_moustafa9@yahoo.com

DOI: 10.21608 /ajnsa.2019.14716.1233

(C) Scientific Information, Documentation and Publishing Office (SIDPO)-EAEA 

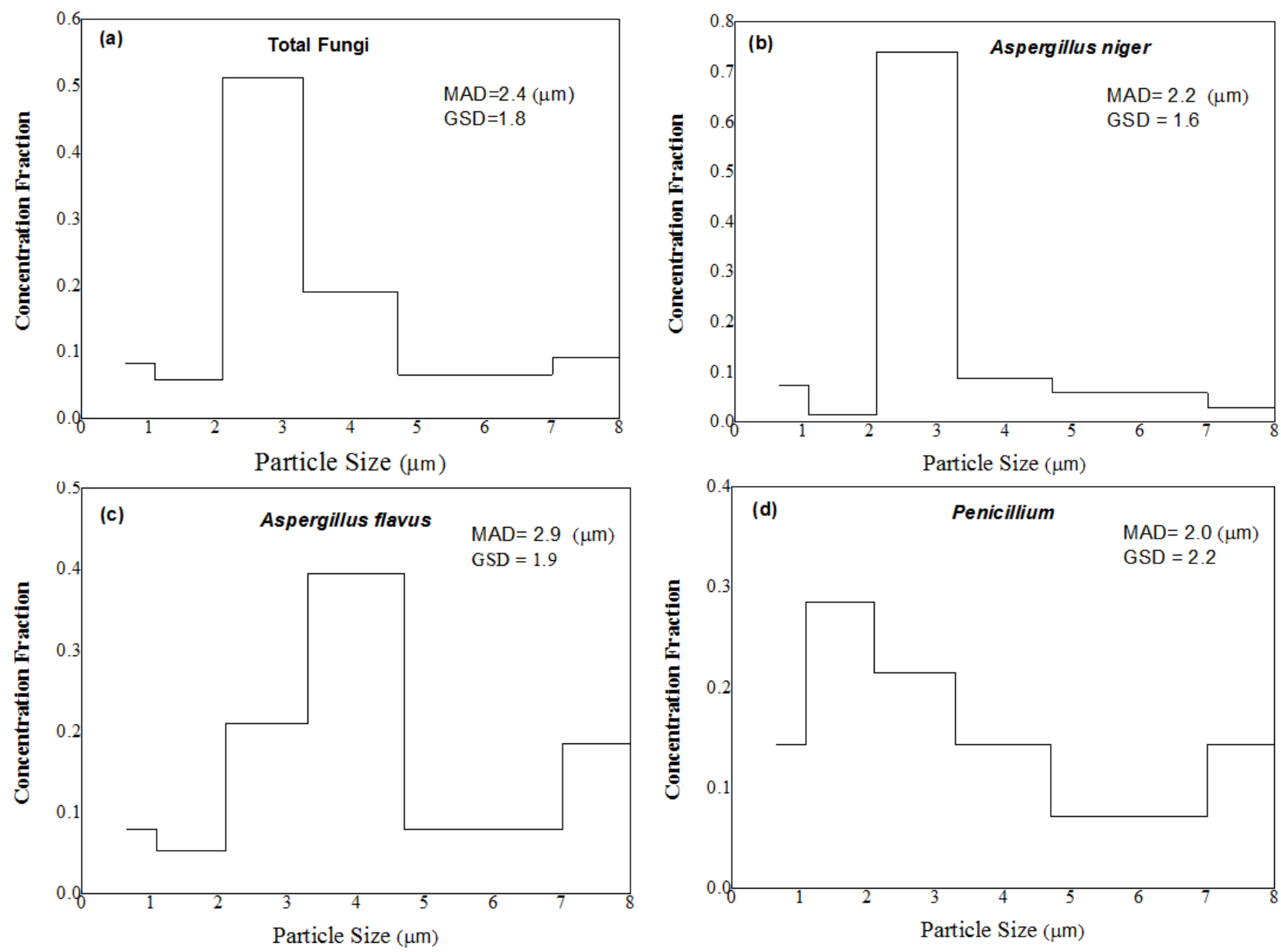

Figure (4): Size distribution of isolated and total fungi

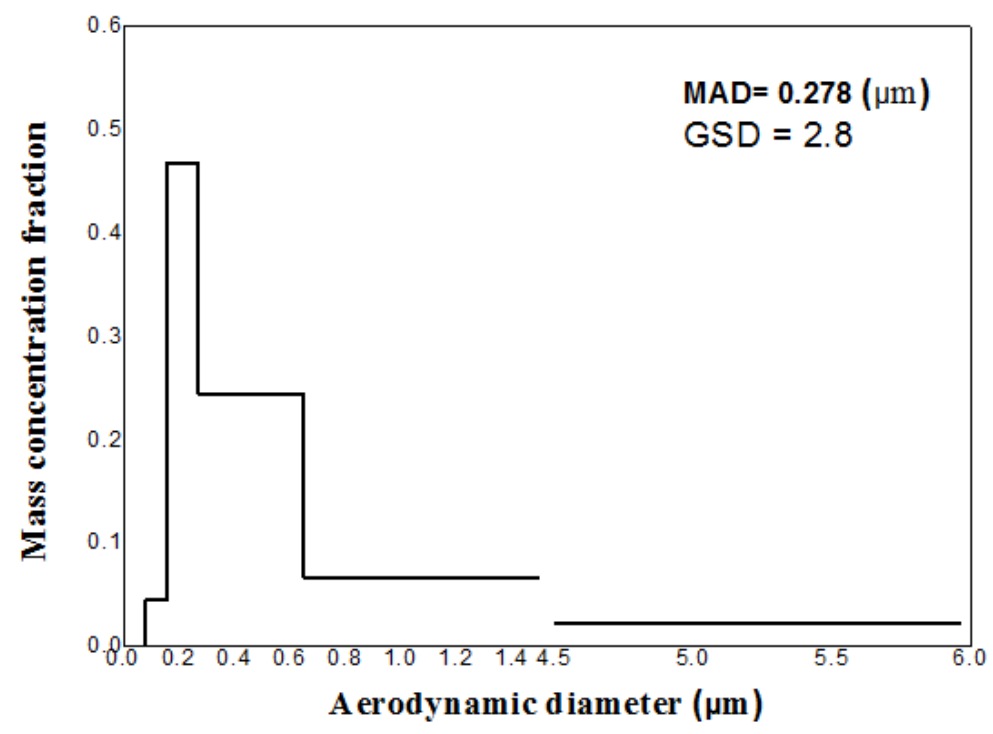

Figure(5): Size distribution of non-biological particles

Mass size distribution of non-biological particles in indoor is illustrated in Figure (5). Mass size distribution of aerosols was bimodal in nature according to the accumulation and coarse modes. Accumulation mode consists of long-lived particles of sizes of a few tenths of a micrometer 
$(0.1 \mu \mathrm{m}<\mathrm{Dp}<2.0 \mu \mathrm{m})$. These particles stay in the atmosphere approximately up to 2 weeks and compete for condensation and coagulation with the particles of the nucleation mode. Due to the larger surface of the accumulation mode particles, the heterogeneous coagulation with them exceeds homogeneous coagulation. On the other hand, the particles in coarse mode $(\mathrm{Dp}>2.0 \mu \mathrm{m})$, are generated by mechanical processes such as erosion, and resuspension and are removed by sedimentation and washout. The coarse particles are characterized by a high deposition velocity and they have short residence times. On the contrary, the residence time of aerosols in the accumulation mode depends on their size, chemistry and height in the atmosphere. These particles remain in the atmosphere longer than the other size categories.

The mass median aerodynamic diameter (MMAD) was $0.3 \mu \mathrm{m}$ with a geometric standard deviation of 2.8. The non-biological aerosols are more distributed than fungal aerosols. The majority of mass size distribution was found to be in the size range $<1.0 \mu \mathrm{m}$ which means that the inhalable particles are the common aerosols. The bimodality nature of mass size distribution was confirmed by many authors $[51,52]$.

Indoor Exposure Dose (IED) of fungal and nonbiological particles

The assessment of infection risk depends not only on the number of inhaled microbes, but also on the individual's body mass [31]. According to this assumption, the dose of bacteria and fungi could be estimated per mean body weight [53]. On the basis of the US Environmental Protection Agency factors $[54,55]$, the IED has been calculated.

Based on the measured microbes concentrations, physical activity of the individuals and the exposure time, the IED was estimated based on the following equation:

$$
\text { IED }=\frac{\text { C. IR. IEF }}{\text { BW }}
$$

where, IED is the indoor exposure dose $(\mathrm{CFU} / \mathrm{Kg})$; $\mathrm{C}$ is the concentration of aerosls $\left(\mathrm{CFU} / \mathrm{m}^{3}\right)$;

IR is the inhalation rate coefficient, characteristic for the physical activity $\left(\mathrm{m}^{3} / \mathrm{h}\right)$;

IEF is the indoor exposure fraction that represents the time spent over a day in the indoor environment (h) and
$\mathrm{BW}$ is the mean body weight $(\mathrm{Kg})$.

In the present study, IR is $0.78 \mathrm{~m}^{3} / \mathrm{h}$ taken for adult assuming light physical activity and the average of IEF if $8 \mathrm{~h}$. Mean body weight (BW) is $75 \mathrm{Kg}$.

The indoor exposure dose, IED of total fungi was 25.6 CFU/Kg while the IED of non-biological particles was $37 \mu \mathrm{g} / \mathrm{Kg}$. Penicillium had the lowest IED, $3 \mathrm{CFU} / \mathrm{Kg}$ while IED of Aspergillus niger had the higest IED, 14.6 CFU/Kg. IED of Aspergillus flavus was $8 \mathrm{CFU} / \mathrm{Kg}$.

IED depends on the concentration of aerosol particles and it is related to the body weight. It was found that the calculated IED is lower than the IED obtained by other authors; where $302.3 \mathrm{CFU} / \mathrm{kg}$ mean IED of bacteria was calculated by Bragoszewska, et al. [53] and $175.4 \mathrm{CFU} / \mathrm{kg}$ by Bragoszewska [56]. The reason of this discrepancy is due to the higher Egyptian body weight compared to others as well as the difference of aerosol concentrations.

\section{Conclusions}

Epidemiological studies reported statistical and positive relation between aerosol particles and increased human mortality and morbidity. People in developed countries spend much of their time in various indoor environments. Lecture rooms and other spaces of schools and universities sometimes represent hazardous and unhealthy environments. Although the concentration of fungi does not exceed the WHO limit, it is in the high category level. Non-biological aerosols exceeds the WHO limit. The high concentration of both aerosols were investigated in the inhalable size range. These particles can be inhaled deeply in the human respiratory tract. It is recommended that more environmental and more public health programs should be conducted in public buildings and particularly in the universities for achieving a healthy indoor environment with a high air quality.

\section{Acknowledgments}

This work was supported by faculty of science, Minia University, El-Minia,Egypt

\section{References}

1-Jyostshna, M., Helmut, B. (2011) Bioaersols in indoor environment - A review with special reference to residential and occupational locations, The Open Eviron \& Biolo Monitor J., (4), 83-96.

2-Pereira, M.L., Knibbs, L.D., He, C., Grzybowski, P., Johnson, G.R., Huffman, J.A., Bell, S.C., Wainwright, C.E.,Matte, D.L., Dominski, F.H., 
Andrade, A., Morawska, L. (2017) Sources and dynamics of fluorescent particles in hospitals, Indoor Air (27), 988-1000.

3-Fabian, M.P., Miller, S.L., Reponen, T., Hernandez, M.T. (2005) Ambient bioaerosol indices for indoor air quality assessments of flood reclamation, $J$. Aerosol Sci., (36),763-783

4-Nasir, Z.A., Colbeck, I. (2010) Assessment of bacterial and fungal aerosol in different residential settings, Water Air Soil Pollut. (211), 367-77.

5-Heikkienen, M.S.A., Hjelmroos-Koski, M.K., Haggblom, M.M., Macher, J.M. (2005) Bioaerosols. In: Ruzer LS, Harley NH, Eds. Aerosols Handbook. Boca Raton: CRC Press 291-342.

6-Manisha, J., Srivastava, R.K. (2013) Identification of indoor airborne microorganisms in residential rural houses of Uttarakhand, India, Int. J. Curr. Microbiol. App. Sci., (2), 146-152.

7-Pillai, S.D., Ricke, S.C. (2002) Bioaerosols from municipal and animal wastes: background and contemporary issues. Can. J. Microbiol., (48), 681696.

8-Wu, Y.H., Chan, C.C., Chew, G.L., Shih, P.W., Lee, C.T., Chao, H.J. (2012) Meteorological factors and ambient bacterial levels in a subtropical urban environment, Int. J. Biometeorol. (56), 1001-1009.

9-Ghosh, B., Lai, H., Kushwaha, R., Hazarika, N., Srivastava, A., Jain, V.K.. (2013) Estimation of bioaerosol in indoor environment in the university library of Delhi, Sustain Environ. Res., (23), 199207.

10-Undochukwu, U., Inetianbor, J., Omorotionmwan, F.O., Okpuruka, N.S. (2016) Effect of high customer patronage on the indoor air quality of restaurants in Lokoja Metropolis and its public health impact, Am. J. Moicrobio. Res., (2), 51-55.

11-Georgakopoulos, D.G., Despres, V., FroehlichNowoisky, J., Psenner, R., Ariya, P.A., Posfai, M., Ahern, H.E., Moffett, B.F., Hill, T.C.J. (2009) Microbiology and atmospheric processes: biological, physical and chemical characterization of aerosol particles, Biogeosciences, ( 6), 721-737.

12-Willeke, K., Baron, P.A. editors (1993) Aerosol measurement: Principles, techniques and applications. New York: Van Nostrand Reinhold.

13-Morawska, L. (1998) Indoor air risk assessment and management Encyclopedia of environmental analyses and remediation.JohnWiley \& Sons, Inc, 2292-2316.

14-Fekadu, H.S., Amanuel, E., Aklilu, D.F. (2015) Quantitative assessment of bio-aerosols contamination in indoor air of university dormitory rooms, Int. J. Health Sci., (3), 249-256.

15-Zemichael, G., Mulat, G., Chalachew, Y. (2016) High bacterial load of indoor air in hospital wards: the case of University of Gondar teaching hospital, Northwest Ethiopia, Multidiscip Respir. Med., (11), 24 doi: 10.1186/s40248-016-0061-4.
16- Samson, E., Ihongbe, J.C., Okeleke- Ochei, Hi Effedua, Phillips Adeyemi O. (2017) Microbiological assessment of indoor air quality of some selected private primary schools in Ilishan-Remo, Ogun state, Nigeria (3), 2454-9142.

17-Kotzias, D. (2005) Indoor air and human exposure assessment-Needs and approaches. Exp. Toxicol. Pathol., (57), 5-7.

18-Yassin, M.F., Almouqatea, S. (2010) Assessment of airborne bacteria and fungi in an indoor and outdoor environment, Int. J. Environ. Sci. Technol., (7), 535544.

19-Fekadu, H.S., Melaku, M.A. (2014) Microbiological quality of indoor air in university libraries, Asian Pac. J. Trop. Biomed., (4), S312-317.

20-Ege, M., Mayer, M., Normand, A., et al. (2011) Exposure to environmental microorganisms and its inverse relation to childhood asthma, Allergy Eur. J. Allergy Clin. Immunol., (6), 57.

21-Després, V.R., Alex Huffman, J., Burrows, S.M., Hoose,C., Safatov, A., Buryak, G., FrohlichNowoisky, J., Elbert, W., Andreae, M., Poschl, U.,Jaenicke, R. (2012) Primary biological aerosol particles in the atmosphere: A review. Tellus $B$ Chem. Phys. Meteorol., 64.

22-Kallawicha, K., Lung, S.C.C., Chuang, Y.C., et al., (2015) Spatiotemporal distributions and land-use regression models of ambient bacteria and endotoxins in the greater Taipei area, Aerosol Air Qual. Res., (15), 1448-1459.

23-Skóra, J., Beata, G., Katarzyna, P., Stępień, Ł., Pietrzak, K., Piotrowska, M., Pietrowski, P. (2015) Assessment of microbiological contamination in the work environments of museums, archives and libraries, Aerobiologia, (31), 389-401.

24-Uk Lee, B., Lee, G., Joon Heo, K.. (2016) Concentration of culturable bioaerosols during winter, J. Aerosol Sci., (94), 1-8.

25-Abdel Hameed, A.A., Khoder, M.I., Ibrahim, Y.H., Yousra, S., Magdah, O., Samah, G. (2012) Study on some factors affecting survivability of airborne fungi, Sci. total environ., (414), 696-700.

26-Hargreaves, M., Parappukkaran, S., Morawska, L., Hitchins, J., He, C., Gilbert, D. (2003) A pilot investigation into associations between indoor airborne fungal and non-biological particle concentrations in residential housesin Brisbane, Australia. Sci. Total Environ., (1), 89-101.

27-Reponen, T., Grishpun, S., Reponen, A., Ulevicius, V. (1996) Characteristics of exposure to fungal spores in indoor air, Am. Indus. Hyg. Asso. http://www.aiha.org/abstract/6evalbio.html,

28-World health organization (2002) Guidelines for concentration and exposure-response measurements of fine and ultrafine particulate matter for use in epidemiological studies. World health organization, Geneva. 
29-Abdel Hameed, A.A., Habeebuallah, T., Mashat, et al. (2015) Airborne fungal pollution at waste application facilities, Aerobiologia, (31), 283-293.

30-Osman, M.E., Abdel Hameed, A.A., Ibrahim, H.Y., Yousef, F., Abo Elnasr, A.A., Saeed, Y. (2017) Air microbial contamination and factors affecting its occurrence in certain book libraries in Egypt, Egy. $J$. Bot. (57), 93-118.

31-Bragoszewska, E., Mainka, A., Pastuszka, J. (2016b) Bacterial and fungal aerosols in rural Nursery schools in southern Poland, Atmos., (7), 142.

32-Jones, W., Morring, K., Morey, P. (1985) Evaluation of the Andersen viable impactor for single sampling, Am. Ind. Hyg. Ass. J., (46), 294-298.

33- Buttner, M.P., Stetsenbach, L.D. (1993) Monitoring of airborne fungal spores in an experimental indoor environment to evaluate sampling methods and the effects of human activity on air sampling, Appl. Environ. Microbiol., (59), 219-226.

34-Reineking, A., Scheibel, H.G., Hussin, A., Becker, K.H., Porestendorfer, J. (1984) Measurements of stage efficiency functions including interstage losses for Sierra and Berner impactors and evaluation of data by modified simplex method, J. Aerosol Sci., (15), 376.

35-World Health organization,WHO (1990) Indoor air quality: biological contaminants.World Health Organization, Copenhagen.WHO- Regional Publications. European series 11031.

36-Platt, S.D., Martin, C.J., Hunt, S.M., Lewis, C.W. (1989) Damp housing,mould, growth and symptomatic health state, Br. Med. J., (298), 16731678.

37-Abdel Hameed, A.A. (2005) Vegetation: A source of air fungal bio-contaminant, Aerobiologia, (21), 5361.

38-Abdel Hameed, A.A., Khoder, M.I., Yuosra, S., Osman, A.M., Ganem, S. (2009) Diurnal distribution of airborne bacteria and fungi in the atmosphere of Helwan area, Egyp, Sci. Total Environ., (407), 6217 6222.

39-World Health organization, WHO Guidelines For air Quality. Geneva

40-Egyptian Environmental Affair Agency, EEAA . (1994) Environmental protection law

41-Abdel Hameed, A., Yuosra, S., Yasser, H., Yousef, F., Mohamed, O. (2018) Air microbial quality in certain public buildings, Egypt: A comparative study, Atmo. Pollu. Res. (9), 617-626.

42-Alghamdi, M.A., Shamy, M., Redal, M.A., et al. (2014) Microorganisms associated particulate matter: A preliminary study. Sci. of the Total Environ, 479480, 109-116.

43-Sadyś, M., Kennedy, R., West, J.S. (2016) Potential impact of climate change on fungal distributions: analysis of 2 years of contrasting weather in the UK., Aerobiologia, (32), 127-37.

44-Darquenne, C. (2012) Aerosol deposition in health and disease, J. of Aerosol Med. Pulm. Drug Deliv. (25), 140-147.

45-Kim, K.Y., Kim, C. N. (2007) Airborne microbiological characteristics in public buildings of Korea, Build Environ., (42), 2188-2196.

46-Li, C.S., Kuo, Y.M. (2014) Characteristics of indoor viable fungi in Taiwan. In: Proceedings of the 6th International Conference on "Indoor Air Quality and Climate", Helsinki, Finland, pp. 183-187. libraries. Asian Pac. J. Trop. Biomed., (4), S312-317.

47-Dekoster, J.A., Thorne, P.S. (1995) Bioaerosol concentrations in noncompliant, compliant, and intervention homes in the Midwest, Am. Ind. Hyg. Assoc. J., (56), 573-580.

48-Pastuszka, J.S., Kyaw Tha Paw, U., Lis, D.O., et al. (2000) Bacterial and fungal aerosol in indoor environment in Upper Silesia, Poland, Atmos. Environ., (34), 3833-3842.

49-Bragoszewska, E., Kowal, A.M., Pastuszka, J.S. (2013) Bacterial aerosol occurring in atmospheric air in Gliwice, Upper Silesia, Poland, Archit. Civ. Eng. Environ., (4), 61-66.

50-Hospodsky, D., Yamamoto, N., Nazaroff, W., Miller, D., Gorthala, S., Peccia, J. (2015) Characterizing airborne fungal and bacterial concentrations and emission rates in six occupied children's classrooms, Indoor air, (25), 641-652.

51-Toscano, G., Moret, I., Gambaro, A., Barbante, C., Capodaglio, G. (2011) Distribution and seasonal variability of trace elements in atmospheric partilcuate in the Venice Lagon, Chimosph. (85), 1518-1524.

52-Mbengue, S., Allenman, L.Y., Flament, P. (2014) Size-distribution metallic elements in submicronic and ultrafine atmospheric particles from urban and industrial areas in northern France, Atmos. Res. (135), 35-47.

53-Bragoszewska, E., Mainka, A., Pastuszka, J. (2016a) Bacterial aerosols in an urban nursery school in Gliwice, Poland: A case study, Aerobiol.,( 32), 469480.

54-US Environmental Protection AgencyChild-specific Exposure factors Handbook (2002) Environmental Protection Agency. Washington, DC, USA.

55-Johnson-Restrepo, B., Kannan, K.. (2009) An assessment of sources and pathways of human exposure to polybrominated diphenyl ethers in United states. Chemos., (76), 542-8.

56-Bragoszewska, E. (2014) Bacterial aerosol occurring in atmospheric air in Gliwice and it is share of the total human exposure to the bacteria absorbed by inhalation. Ph. D. Thesis. Silesian university of technology, Gliwice, Poland. 